\title{
Effect of spacing on growth, flowering and corm production of gladiolus (Gladiolus sp.) cv. American Beauty
}

\author{
Kuldip Kumar, C. N. Singh, V. S. Beniwal, Rohit Pinder \\ Chaudhary Charan Singh University, Meerut, Uttar Pradesh, India
}

\begin{abstract}
A study was conducted to evaluate the effect of plant density on growth, flowering corm and cormel production of gladiolus (Gladiolus sp.) cv. American Beauty at the farm of the Department of Horticulture, C.C.R (P.G.) College, Muzaffarnagar (Uttar Pradesh). The experiment was laid out in randomized complete block design with four replications and three spacing's viz. $S_{1}$ $(40 \mathrm{~cm} \times 20 \mathrm{~cm}), S_{2}(30 \mathrm{~cm} \times 40 \mathrm{~cm})$ and $S_{3}(40 \mathrm{~cm} \times 40 \mathrm{~cm})$. The observations were recorded for various vegetative, floral and corm parameters. Maximum germination percentage $(86.71 \%)$, plant height $(105.66 \mathrm{~cm})$ and number of leaves per plant (8.01), number of days taken for initiation of spike (94.13 days), number of spikes per plant (0.96), length of spike (81.56cm ), number of florets per spike (17.86) and duration of flowering (18.54 days) was found with $30 \mathrm{~cm} \times 40 \mathrm{~cm}$ spacing $\left(S_{2}\right)$. However, number of corms per plant (1.31), number of cormels per plant (21.56), weight of corms per plant (57.68g), weight of cormels per plant $(36.43 \mathrm{~g}$ ) was found maximum with $40 \mathrm{~cm}$ $x 40 \mathrm{~cm}$ spacing $\left(S_{3}\right)$ which was at par with $S 2$, whereas, yield of corms and cormels per plot (3.18) was found maximum with $40 \mathrm{~cm} \times 20 \mathrm{~cm}$ spacing $\left(S_{1}\right)$.
\end{abstract}

Hence, $30 \mathrm{~cm} \times 40 \mathrm{~cm}$ spacing can be recommended for the commercial cultivation of gladiolus.

Keywords-Spacing, corm, cormel, spike, gladiolus.

\section{INTRODUCTION}

Gladiolus, a member of family Iridaceae is also known as queen of bulbous flowers, as there is no flower to surpass its beauty in the cut flower industry. It is also known as "Sword lily" because of the shape of its leaves. Its cultivation is getting popular for its striking colours occurring naturally in the stripes, dots, splashed bicoloured and multicoloured florets having a longer life as cut flowers. Its magnificent inflorescence with variety of colours and number of pretty florets has made it very attractive for diversified use in the garden. It is an important cut-flower in both domestic and international market (Chanda et al., 2000).

The productivity, quality of spikes, corms and cormels produced are known to influence by several factors such as cultivar, agro-techniques, nutrition, plant density etc. so it is imperative to provide more information to the growers for higher productivity and quality. However, number of spikes, corms and cormels produced per plot was affected by plant spacing (Singh and Bijimol, 2003). The performance of bulbous crops is greatly influenced by spacing. Spacing has been found to influence growth, flowering and yield of daughter bulbs in gladiolus (Mukhopadhyay and Yadav, 1984). The optimum spacing helps not only in obtaining good quality cut flowers but also in better utilization of land, providing good open position for sunlight, soil moisture conservation, weed control and availability of nutrients vital for successive crop production and quality (Sanjib et al., 2002).

Keeping this in view, the present investigation was conducted with an objective of studying the plant density on growth, flowering, corm production and vase life of gladiolus.

\section{MATERIALS AND METHODS}

An experiment was conducted to determine the effect of plant density on growth, flowering and corm and cormel production of gladiolus (Gladiolus sp.) cv. American Beauty at the farm of the Department of Horticulture, C.C.R (P.G.) College, Muzaffarnagar (Uttar Pradesh) for two years and the data were pooled. The experiment was laid out in randomized complete block design with four replications and three spacing's.

The size of the plots was $4 \mathrm{~m}^{2}(2 \mathrm{~m} \times 2 \mathrm{~m})$ having three different treatments (spacings) viz. $S_{1}(40 \mathrm{~cm} \times 20 \mathrm{~cm}), S_{2}$ $(30 \mathrm{~cm} \times 40 \mathrm{~cm})$ and $S_{3}(40 \mathrm{~cm} \times 40 \mathrm{~cm})$. The variety adopted was American beauty, which shows good performance in Muzzafarnagar (U.P.) conditions. 
Soil samples were taken and were analyzed and $\mathrm{pH}$ of soil was done according to Piper (1966) and available nitrogen in soil. (Subhiah and Asija, 1956)

Table.1: Chemical characteristics of experimental soil (Horticulture farm, Department of Horticulture, C.C.R (P.G.) College, Muzaffarnagar) Chemical analysis

\begin{tabular}{|l|c|}
\hline Chemical composition of soil & Percentage \\
\hline Nitrogen & 0.03 \\
\hline Phosphorous & 0.10 \\
\hline Potassium & 1.05 \\
\hline Organic carbon & 0.49 \\
\hline
\end{tabular}

The crop was raised by using standard cultural practices. The observations were recorded for vegetative traits like number of days for complete sprouting, germination percentage, number of sprouts per corm, plant height, number of leaves per plant, flowering traits like number of days taken for spike initiation, number of spike per plant, spike length, number of florets per spike, size of florets and flower longevity in field and corms traits like number of corms and cormels, size of corms per plot, weight of corms and cormels per plant and yield of corms per plot and were statistically analyzed as per the procedure outlined by applying the technique of analysis of variance (ANOVA) as suggested by Panse and Sukhatme (1967). All the statistical analysis was carried out by using OPSTAT statistical software.

\section{RESULTS AND DISCUSSION}

The results obtained from the present investigation as well as relevant discussion have been summarized under the following heads:

\section{Vegetative characters}

1. Number of days for complete sprouting

It is evident from the table 2 that time taken for complete sprouting was influenced by different spacing. However, early sprouting (25.05 days) was observed in $S_{3}(40 \mathrm{~cm} \times 40 \mathrm{~cm})$ followed by $S_{2}$ whereas maximum number of days (27.01 days) for complete sprouting was found in $S_{1}$. The time taken for complete sprouting was found to be Nonsignificant.

2. Germination percentage

A significant effect on germination percentage was found for spacing as shown in table 2. Comparison of different spacings reveals that in $S_{2}$ spacing resulted in higher germination percentage $(86.71 \%)$ while, minimum in $\mathrm{S}_{1}(82.23 \%)$. The percentage of germination was more with medium and wider spacing because of more congenial conditions for plant growth and lesser competition among the plants.

3. Number of sprouts per corm

It is clear from table 2 reveals that there was nonsignificant effect w.r.t maximum number of sprouts per corm (1.55) was observed with wider spacing $S_{3}$ whereas minimum (1.20) was observed in $S_{1}$. Optimum spacing produced more number of sprouts per corm.

Table.2: Effect of spacing on vegetative traits of gladiolus (Gladiolus sp.) cv. American Beauty

\begin{tabular}{|l|c|c|c|c|c|}
\hline Treatments & $\begin{array}{l}\text { Number of days } \\
\text { for } \\
\text { sprouting (Days) }\end{array}$ & $\begin{array}{l}\text { Germination } \\
\text { percentage (\%) }\end{array}$ & $\begin{array}{l}\text { Number of } \\
\text { sprouts per corm }\end{array}$ & $\begin{array}{c}\text { Plant Height } \\
(\mathbf{c m})\end{array}$ & $\begin{array}{l}\text { Number of } \\
\text { leaves per } \\
\text { plant }\end{array}$ \\
\hline $\mathbf{4 0 c m} \times \mathbf{2 0} \mathbf{c m}$ & 27.01 & 82.23 & 1.20 & 101.87 & 7.82 \\
\hline $\mathbf{3 0 c m} \times \mathbf{4 0 c m}$ & 25.94 & 86.71 & 1.42 & 105.66 & 8.00 \\
\hline $\mathbf{4 0 c m} \times \mathbf{4 0 c m}$ & 25.05 & 85.58 & 1.55 & 104.78 & 7.96 \\
\hline CD at 5\% & N.S. & 5.00 & N.S. & 1.68 & 0.14 \\
\hline
\end{tabular}

\section{4.}

Plant height

Comparison of data in table 2 reveals that spacing significantly affects the plant height. Maximum plant height $(105.66 \mathrm{~cm})$ was observed in plants grown at a spacing of $30 \mathrm{~cm} \times 40 \mathrm{~cm}\left(\mathrm{~S}_{2}\right)$ which was at par with $S_{3}$ whereas, minimum $(101.87 \mathrm{~cm})$ was observed with $\mathrm{S}_{1}$. Plant height depends upon the availability of moisture and nutrients from the soil and genetic composition. Uptake of moisture, nutrients and utilization of more sunlight allow the plant to grow more rapidly than closer spacing. This allows the plants to synthesize more carbohydrates and hormones like $\mathrm{GA}_{3}$ that enhanced longitudinal growth as internodal length 
and resulted in longer plants. Variation in plants height is due to difference in genetic constitution of the cultivars which responded differently to the available spacing/environment. Similar results were obtained by Bahar and Korkut (1998).

\section{Number of leaves per plant}

Maximum number of leaves (8.00) was found with $30 \mathrm{~cm} \times 40 \mathrm{~cm}$ spacing which was significantly at par with $\mathrm{S}_{3}$, whereas minimum number of leaves (7.82) was found in $S_{1}$ as shown in table 2. The positive response of wider spacing provide space between the plants resulting in absorbed optimum amount of nutrients with sufficient light, which ultimately favorable for photosynthesis and translocation of assimilates into the storage organs. Leaves produced per plant were more in the plants grown with wider spacing when compared to those grown with closer spacing (Mukhopadhyay and Yadav, 1984). Similarly, variations in number of leaves were also recorded by Sujatha and Singh, (1991) in Gladiolus.

\section{Flowering traits}

\section{Number of days taken for spike initiation}

It is evident from the table 3 that the spike emergence was early (91.90days) in the plants with wider spacing $\mathrm{S}_{3}$ and was significantly superior to all the other treatments whereas, maximum days (94.46days) were taken for spike emergence under $\mathrm{S}_{1}$. According to the findings of M. Jamil Ahmed et al. in 2010, in gladiolus cv. Blad jack developed spikes with comparatively wider plant spacing $(25 \mathrm{~cm} \times 30 \mathrm{~cm})$. This might be due to reduction in growth at narrow spacing $(15 \mathrm{~cm} \times 30 \mathrm{~cm})$ and $(20 \mathrm{~cm} \times 30 \mathrm{~cm})$ that directed the plant towards the reproductive phase earlier than the plants that have more vegetative difference in genetic composition of the cultivars that respond differently to the environment. Similar to our findings it has been observed that early spike emergence and flowering occurred in tuberose at wider spacing $(30 \mathrm{~cm} \mathrm{x}$ $30 \mathrm{~cm}$ ) planting distances than narrow one. (Mane et al., 2006).

\section{Number of spike per plant}

Perusal of data presented in table 3 showed that the maximum number of spikes (0.96) per plant was observed in plants spaced at $30 \mathrm{~cm} \times 40 \mathrm{~cm}\left(\mathrm{~S}_{2}\right)$ which was significantly at par with $\mathrm{S}_{3}$, while minimum number of spikes per plant $(0.86)$ was observed at spacing of $40 \times 20 \mathrm{~cm}$. Spacing of corms at medium and wider spacing resulted in highest number of spikes per plant. This was due to the fact that in wider spacing; the plants face lesser competition for water and minerals than the plants at closer spacing. The results of present investigation are similar to those obtained by Mukhopadhyay and Yadav (1984).

3. Spike length

Data presented in table 3 indicates that variation in spike length among different levels of spacing was found to be highest $(81.56 \mathrm{~cm})$ in medium spacing $(30 \mathrm{~cm} \times 40 \mathrm{~cm})$ which was significantly at par with $\mathrm{S}_{3}$ whereas, lowest spikes length $(79.33 \mathrm{~cm})$ was found in $S_{1}$. This result is supported by Mane et al., (2007). This might be due to the fact that at wider spacing uptake of more moisture, nutrients and utilize more sunlight allow the plant to grow more rapidly than closer spacing which ultimately favorable for photosynthesis and translocation of assimilates into the storage organs. This allows the plants to synthesize more carbohydrates and hormones like $\mathrm{GA}_{3}$ that enhanced longitudinal growth as internodal length and resulted in increase in spike length.

4. Number of florets per spike

Comparison of different spacing given in table 3 reveals that the maximum number of florets per spike (17.86) was observed in plants planted at a spacing of $30 \times 40 \mathrm{~cm}\left(\mathrm{~S}_{2}\right)$ which was significantly at par with $\mathrm{S}_{3}$, while minimum was observed under lowest spacing $S_{1}$ (16.87). Medium and wider spacing recorded highest number of florets per spike. This might be due to less competition between plants for water, minerals, nutrients and light. Mukhopadhyay and Banker (1991), Arora and Khanna (1987) and Roychowdhary (1989) reported similar results.

Table.3: Effect of spacing on flowering traits gladiolus (Gladiolus sp.) cv. American Beauty

\begin{tabular}{|l|c|c|c|c|c|c|}
\hline Treatments & $\begin{array}{l}\text { Number of days } \\
\text { taken for spike } \\
\text { initiation }\end{array}$ & $\begin{array}{l}\text { Number of } \\
\text { spike per plant }\end{array}$ & $\begin{array}{l}\text { Spike length } \\
(\mathbf{c m})\end{array}$ & $\begin{array}{l}\text { Number of } \\
\text { florets } \\
\text { spike }\end{array}$ & $\begin{array}{l}\text { Size of florets } \\
\text { per }\end{array}$ & $\begin{array}{l}\text { Flower } \\
\text { longevity } \\
\text { (days) }\end{array}$ \\
\hline $\mathbf{4 0 c m} \times \mathbf{2 0} \mathbf{c m}$ & 94.46 & 0.86 & 79.33 & 16.87 & 10.74 & 16.05 \\
\hline
\end{tabular}




\begin{tabular}{|l|c|c|c|c|c|c|}
\hline $\mathbf{3 0 c m} \times \mathbf{4 0 c m}$ & 94.13 & 0.96 & 81.56 & 17.86 & 10.84 & 18.54 \\
\hline $\mathbf{4 0 c m} \times \mathbf{4 0 c m}$ & 91.90 & 0.95 & 80.49 & 17.35 & 10.67 & 18.89 \\
\hline CD at 5\% & 2.01 & 0.11 & 1.16 & 0.89 & N.S. & 1.28 \\
\hline
\end{tabular}

\section{Size of florets}

It is depicted in the table 3 that maximum size of florets was found in medium spacing $(10.84 \mathrm{~cm})$ and was non-significantly higher with all other treatments. Wider spaced plants have less competition between plants for water, minerals, nutrients and light resulted into better quality production are in conformity, but florets size has not affected significantly by plant spacing. These results were agreed with Bijmol and Singh (2001) in gladiolus.

\section{Flower longevity in field}

Maximum longevity of flowers in the field (18.89days) was observed in plants grown at a spacing of $40 \times 40 \mathrm{~cm}\left(\mathrm{~S}_{3}\right)$ which was significantly at par with $\mathrm{S}_{2}$ whereas, minimum longevity of flowers (16.05days) was observed with $\mathrm{S}_{1}$ (Table 3). Widest spacing recorded with the highest duration of flowering as compared to closest spacing. Similar results were found by mane et al., in 2007 on tuberose vase life. These results were in agreement with the findings of Singh and Bijmol (2003) where widest spacing recorded maximum longevity as compared to closest spacing. This might be due to availability of more area per plant for absorption of nutrients and moisture, no shading effect which ultimately increased the rate of net photosynthesis and translocation of assimilates to the storage organs. The carbohydrate reserves in the flower and spike probably maintains pool of dry matter and repairable substance, especially in petals, thus promoting respiration and extending longevity in gladiolus.

\section{Corms and Cormels traits}

1. Number of corms and cormels per plant Comparison of different spacing reveals that the maximum number of corms (1.31) and cormels (21.56) per plant was observed in plants planted at a spacing of $40 \times 40 \mathrm{~cm} \quad\left(\mathrm{~S}_{3}\right)$ which was significantly at par with $\mathrm{S}_{2}$, while minimum was observed under lowest spacing $\mathrm{S}_{1}$ (Table 4). Similar results were shown by Mane et al., (2006) in tuberose where maximum number of bulbs, with greater weight and size were observed. This might be due to the reason that the numbers of leaves were highest which resulted in the production of more photosynthates in the plant which transferred towards the root.

Table.4: Effect of spacing on number of corms, cormels per plant and size of corms

\begin{tabular}{|c|c|c|c|c|c|c|}
\hline Treatments & $\begin{array}{l}\text { Number of } \\
\text { corms per plant }\end{array}$ & $\begin{array}{lr}\text { Number } & \text { of } \\
\text { cormels } & \text { per } \\
\text { plant } & \end{array}$ & $\begin{array}{l}\text { Size of corms } \\
(\mathrm{cm})\end{array}$ & $\begin{array}{lr}\begin{array}{l}\text { Weight } \\
\text { corms }\end{array} \\
\text { plant }\end{array}$ & $\begin{array}{l}\text { Weight of } \\
\text { cormels per } \\
\text { plant }\end{array}$ & $\begin{array}{l}\text { Yeild of } \\
\text { corms per } \\
\text { plot }\end{array}$ \\
\hline $40 \mathrm{~cm} \times 20 \mathrm{~cm}$ & 1.08 & 16.43 & 5.29 & 47.06 & 21.3 & 3.18 \\
\hline $30 \mathrm{~cm} \times 40 \mathrm{~cm}$ & 1.25 & 18.24 & 5.36 & 55.09 & 25.89 & 2.65 \\
\hline $40 \mathrm{~cm} \times 40 \mathrm{~cm}$ & 1.31 & 21.56 & 5.32 & 57.68 & 36.43 & 2.39 \\
\hline CD at $5 \%$ & 0.21 & 5.17 & N.S. & 10.05 & 7.26 & 0.03 \\
\hline
\end{tabular}

\section{Size of corms per plot}

Non-significant variations were found regarding different spacing however maximum size of corms $(5.36 \mathrm{~cm})$ was recorded with $30 \mathrm{~cm} \times 40 \mathrm{~cm}$ spacing (Table 4). This might be due to the reason that under wider spacing competition between plants for space, nutrient, water was lowest and secondly growth was also highest in wider spacing. Yadav et al., (2007) observed that all the corm and cormel parameters increased with the spacing. But the size of corms has not affected significantly by plant spacing.

3. Weight of corms and cormels per plant

Close observation of the results on weight showed that $\mathrm{S}_{3}$ spacing increases the weight of corms $(57.68 \mathrm{~g})$ and cormels (36.43g) which was significantly at par with $S_{2}$ whereas, $S_{1}$ reduced the weight of corms and cormels (Table 4). This may be due to availability of more area per plant for absorption of nutrients and moisture, no shading effect which ultimately increases the rate of net 
photosynthates and translocation of assimilates to the storage organs.

4. Yield of corms per plot

Maximum yield of corms $(3.18 \mathrm{~kg})$ per plot was found with closer spacing $\mathrm{S}_{1}$ which was significantly higher with other treatments where as minimum yield (2.39) was found with wider spacing $\mathrm{S}_{3}$. It was highest with closer spacing and lowest with wider spacing. But Cirrito and Vita, (1980) reported that cormel production was not affected by plant density in gladiolus. But Mukhopadhyay and Yadav, (1984) recorded more yield of corms and cormels per square meter with closer spacing.

\section{CONCLUSION}

Plant spacing affects the growth, yield and quality of gladiolus cv. American beauty. Gladiolus cultivar under study presented variability in vegetative, reproductive and corm and cormel characteristics on different plant spacing. Cultivar under the study showed better performance at comparatively medium spaces than narrow one. Hence, medium spacing $(30 \mathrm{~cm} \times 40 \mathrm{~cm})$ is recommended for general cultivation of gladiolus.

\section{REFERENCES}

[1] Ahmed, M.J., T. Bashir, A. Yaqoob, M.S. Jillani and M. Saeed. 2010. Effect of plant spacing on vegetative and reproductive growth of gladiolus cultivars. Sarhad J. Agric 26(4): 539-543.

[2] Arora, J.S., and Khanna, K. 1987. Spacing effects on flower and corm production of gladiolus cv. Sylvia Indian J.Hort 44(1/2): 92-99.

[3] Bahar, S.N.G., and Korkut, A.B. 1998. Research on effects of planting densities on the yield of corm and cormel in some gladiolus varieties. Turkish Journal of Agriculture and Forestry 22(1): 51-58.

[4] Bijimol, G., and Singh, A.K. 2001. Effect of spacing and nitrogen on flowering, flower quality and postharvest life of gladiolus. J. Appl. Hort 3: 48-50.

[5] Chanda, S., Barma, G., and Roychowdhury, N. 2000. Influence of different level of nitrogen, phosphorus and potassium on growth and flowering of gladiolus. The Horti. J 13(1): 76-86.

[6] Chattopadhyay, T.K., Biswas, M.R., and Jana, S.C. 1992. Nitrogen and Phosphorous effect on growth and production of gladiolus (cv. Vink's glory). Annals of Agricultural Research 13(2): 191-192.
[7] Cirrito, M., and M. De. Vita. 1980. A comparison of three different planting densities for increasing the size of gladiolus corms. Ann. Dell. Inst. Speri. Flori 11(1): 169-194.

[8] Mane, P. K., Bankar, G. H., and Makne, S. S. 2006. Effect of spacing, bulb size and depth of planting on growth and bulb production in tuberose (Polianthes tuberosa) cv. Single. Indian J. Agric. Res 40(1): 6467.

[9] Mane, P.K., Bankar, G.J., and Makne, S.S. 2007. Influence of spacing, bulb size and depth of planting on flower yield and quality of tuberose (Polianthes tuberosa L.) cv. Single. Indian J. Agric. Res 41(1): 71 -74 .

[10] Mukhopadayay, A. and Bankar, G.J., 1981. Effect of time of planting on growth, flowering and bulb production in tuberose cv. Single. Indian Agric 25: 131-134.

[11] Mukhopadhyay, T.P., and Yadav, L.P. 1984. Effecto of corm size and spacing on Growth, flowering and corm production in gladiolus. Haryana J. Hort. Sci 13(3-4): 95-99.

[12] Panse, V. G., and Sukhatme, P. V. 1967. Statistical Methods for Agricultural Workers, I.C.A.R., Pub. New Delhi pp. 336.

[13] Piper, C.S. 1966. Soil and Plant Analysis. Hans Publications, Bombay pp. 368.

[14] Sanjib, S., Talukdar, Sharma, S., Misra, R.L., and Sanyat, M. 2002. Effect of time spacing and depth of planting gladiolus. Flori. Res. Trend India 7: 243-245.

[15] Singh, A. K., and Bijimol, G. 2003. Effect of spacing and nitrogen on gladiolus. J. Ornam. Horti 6(1): 7375.

[16] Singh, Mahendra. 1984. Diagnosis of nutrient deficiency. Fertilizer and water use guide. Dept. Soil Sci. HAU, Hisar pp. 28.

[17] Subhiah, B.V., and Asija, G.L. 1956. A rapid procedure for determination of available $\mathrm{N}$ in soil. Curr. Sci 25: 259-260.

[18] Sujatha, K., and Singh, K.P. 1991. Effect of different planting densities on growth, flowering and corm production in gladiolus. Indian J. Hort 48(3): 273-276.

[19] Yadav, S.K., and A.K. Tyagi. 2007. Effect of corm size and spacing on growth and flowering of gladiolus cv. Sylvia. Plant Archives 7(1): 343-344. 